УДК 330.341: 658

DOI: https://doi.org/10.37320/2415-3583/11.40

Трофименко О.O.

кандидат економічних наук, дочент, доцент кафедри економіки та підприємництва, Міжнародний університет фінансів; доцент кафедри теоретичної та прикладної економіки, Начіональний технічний університет Украӥни «Київський політехнічний інститут імені Ігоря Сікорського» ORCID: https://orcid.org/0000-0002-2339-0377

Дорошкевич Д.В.
доктор економічних наук, дочент,
завідувач кафедри економіки та підприємничтва,
Міжнародний університет фінансів;
професор кафедри менеджменту видавничо-поліграфічної галузі,
Національний технічний університет Украйни
«Київський політехнічний інститут імені Ігоря Сікорського»
ORCID: httрs://orcid.org/0000-0003-0421-0630

Джадан I.M.

аспірантка відділу секторальної економіки, Національний інститут стратегічних досліджень; старший викладач кафедри економіки та підприємництва, Міжнародний університет фінансів ORCID: https://orcid.org/0000-0003-3887-4312

\title{
ВИКОРИСТАННЯ ЗАСАД ГЛОБАЛЬНИХ ЦІЛЕЙ СТАЛОГО РОЗВИТКУ ДЛЯ ЗАБЕЗПЕЧЕННЯ РОЗВИТКУ ПРОМИСЛОВОСТІ УКРАЇНИ
}

У статті досліджено основні тендениії розвитку промисловості України. Обрано основні Глобальні иілі сталого розвитку на основі яких має забезпечуватися розвиток промисловості Украйни, а саме: Ціль 8 «Гіна праия та економічне зростання», Ціль 9 «Інновації й інфраструктура», Ціль 12 «Відповідальне споживання», Ціль 17 "Співпрачя заради досягнення иілей». Досліджено основні передумови розвитку промисловості. Співставлено динаміку індексів валового внутрішнього продукту та промислової продукиії. Визначені основні країни, які доцільно використовувати як орієнтири для аналізу прогресу досягнення иілей сталого розвитку та розвитку промисловості. Наведено динаміку реального ВВП на душу населення в досліджуваних краӥнах та в Україні. Визначені основні негативні та позитивні аспекти розвитку промисловості на засадах глобальних иілей сталого розвитку. Досліджено окремі показники ефективності заходів щзодо досягнення визначених изілей сталого розвитку в Украӥні.

Ключові слова: промисловість, сталий розвиток, глобальні иілі сталого розвитку.

Постановка проблеми. Сьогодні, в умовах Індустрії 4.0, забезпечення інноваційного розвитку промисловості та приведення промислового комплексу України до провідних світових стандартів є нагальною потребою. Так, в березні 2020 р. Європейська комісія представила Нову Промислову Стратегію $\mathrm{CC}$, яка спрямована на реалізацію трьох ключових пріоритетів: 1) підтримка глобальної конкурентоспроможності європейської промисловості та єдиних правил гри (рівних умов) на національному та глобальному рівнях; 2) перетворення Європи на кліматичнонейтральну до 2050 року; 3) формування цифрового майбутнього Європи [1]. Також 18 червня 2020 р. Європейська Комісія ухвалила прийняття Європейським Парламентом Регламенту таксономії - ключового законодавчого акту, який сприятиме європейській «зеленій угоді», стимулюючи інвестиції приватного сектору в «зелені» та стійкі проекти. Це сприятиме створенню першого у світі «зеленого списку» - класифікаційну систему класичної стійкої економічної діяльності - що сформує універсальну мову, якою інвестори можуть користуватися скрізь, інвестуючи в перспективні проекти та економічну діяльність реального сектору, які мають істотний позитивний вплив на клімат і навколишнє середовище [2]. Відповідно до ознак економічної класифікації Міжнародного валютного фонду сьогодні Україна входить до групи країн «Нова Європа, яка розвивається» (Emerging and Developing Europe) та відносини України з СС підкріплені політичною асоціацією та економічною інтеграцією. Саме тому, сьогодні в Україні триває процес доопрацювання Стратегії розвитку промислового комплексу до 2025 р. з огляду на пріоритети нової промислової стратегії 
ЄС. Успішне формування власної стратегії розвитку промислового комплексу, яка буде враховувати європейські виклики та цінності $€ \mathrm{C}$, дозволить підвищити якість промислової продукції України та іï глобальну конкурентоспроможність.

У даному дослідженні нами було виокремлено цілі серед Глобальних Цілей сталого розвитку до 2030 р., затверджених на саміті ООН з питань сталого розвитку [3], на засадах яких доцільно розвивати промисловість України. Було проаналізовано основні показники промислового розвитку та його інфраструктурного забезпечення.

Аналіз останніх досліджень і публікацій. Дослідженням питань розвитку промисловості України, іiі ролі та місця в національній економіки присвячені праці багатьох вітчизняних вчених: О. Амоші, С. Войтка, С. Ілляшенка, Л. Федулової, Н. Чухрая, В. Геєця., В. Захарченка та ін. Визначаючи вагомий внесок вчених у розвиток досліджуваної проблематики, залишаються не достатньо визначеними сучасні потреби та пріоритети розвитку промисловості в Україні, які обумовлені швидкими трансформаційними змінами в світі.

Метою дослідження $\epsilon$ визначення тенденцій розвитку промисловості України з врахуванням Глобальних цілей сталого розвитку для формування рекомендацій щодо основних стратегічних заходів для іiі розвитку.

Виклад основного матеріалу. Сімнадцять Глобальних Цілей сталого розвитку були затверджені у 2015 році на саміті ООН з питань сталого розвитку. Для нашого дослідження обрали чотири цілі, які стосуються або позитивно впливають на економічне зростання та промисловий розвиток країни, а саме: Ціль 8 «Достойні робочі місця та економічне зростання», Ціль 9 Інновації й інфраструктура», Ціль 12 «Відповідальне споживання», Ціль 17 «Співпраця заради досягнення цілей».

В Україні під час адаптації цілей сталого розвитку, кожна глобальна ціль була переглянута 3 урахуванням специфіки національного розви- тку. Результатом такого перегляду, в тому числі, стала відмова від глобальної концепції формування за цілями суміжних (спільно спрямованих, повторних за суттю) завдань, при цьому при визначенні релевантних завдань було збережено принцип взаємозалежності та впливовості. Загалом на національному рівні в основу була покладена теза, що саме ЦСР 8, з одного боку, $є$ засобом досягнення інших 16 цілей, з іншого - це кінцева мета до 2030 року.

Одним 3 основних індикаторів економічного зростання є ВВП країни. Тому доцільно проаналізувати динаміку його індексу порівняно 3 індексом промислової продукції, який визначається у вигляді відношення поточного обсягу виробництва (у грошовому вираженні) до обсягу промислового виробництва в попередньому періоді та базується на використанні даних про динаміку виробництва видів продукції за встановленим постійним набором товарів-представників важливіших видів промислової продукції (близько 1000 позицій). Динаміку індексу ВВП та індексу промислової продукції подали на рис. 1. Так, з 2010 по 2015 рр. спостерігалося зниження індексу промислової продукції майже на 22\%. 32015 по 2016 рр. відбулося зростання індексу промислової продукції майже на 19\%, далі з 2016 по 2019 рр. відбувалися незначні коливання даного індексу і в 2019 р. він становив 99,5. За даними [4] в умовах загострення конкурентної боротьби та необхідності технологічного переозброєння, у 2019 р. промислові підприємства масово проводили модернізацію. Так, за перші 9 місяців 2019 р. капітальні інвестиції в добувній промисловості зросли на $34 \%$, у постачанні електроенергії та газу - на $38 \%$, у харчовій промисловості - на $42 \%$, у металургії - на $34 \%$. Крім того, збільшився чистий приплив прямих іноземних інвестицій до реального сектору економіки - до 2.3 млрд дол. США, що у 1.7 рази перевищує рівень 2018 р. (1.4 млрд дол. США).

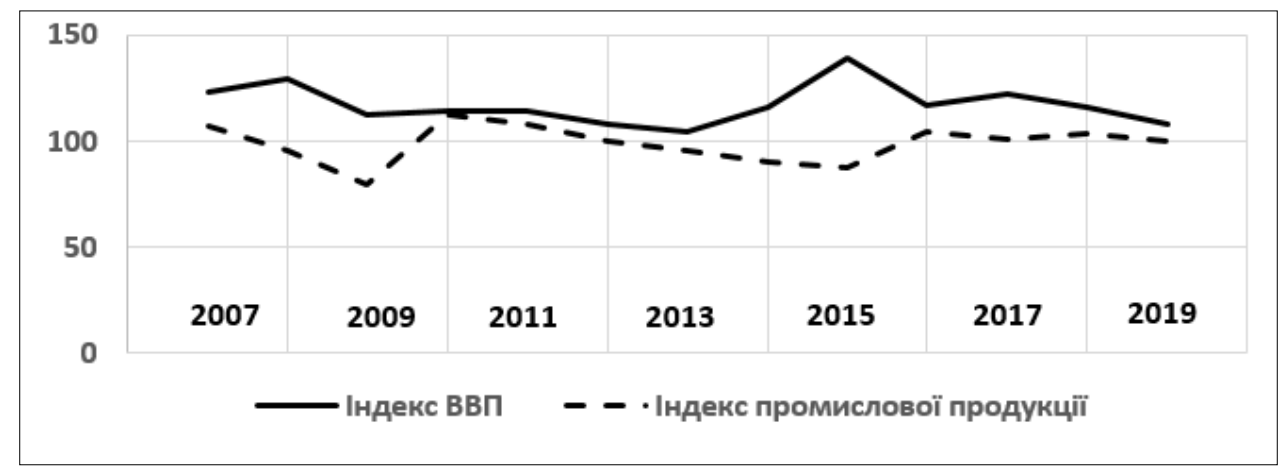

Рисунок 1 - Динаміка індексу валового внутрішнього продукту та індексу промислової продукції України у 2007-2019 pp.

Джерело: розроблено авторами на основі [5] 
У той же час, проведення капітальних ремонтів і оновлення ліній теж певним чином гальмувало роботу та знижувало показники цих галузей, водночас створюючи підгрунтя для майбутніх результатів. Цим можна пояснити відставання зростання індексу промислової продукції від індексу ВВП. У цілому, вже у січні 2020 р. року зросли обсяги виробництва прокату - на 29,4\%, сталі - на 14,6\% та чавуну - на $4,9 \%$.

У той же час, при порівнянні України з іншими країнами (Канада, Німеччина, Франція, Велика Британія, Італія, Португалія, Естонія, Угорщина, Латвія, Литва, Туреччина та Білорусь) за показником реального ВВП на душу населення Україна посідає останнє місце (рис. 2). Зазначимо, що країни для порівняння були обрані за такими критеріями: країни-сусіди, схожі ресурсні можливості, країни, з якими Україна співпрацює за різними напрямами, країни 3 провідною економікою та високим рівнем ВВП. Так, наприклад, Туреччина $є$ країною, що тісно співпрацює з Україною і в січні 2020 р. в Анкарі пройшов черговий раунд переговорів щодо укладення Угоди про вільну торгівлю між Україною та Турецькою Республікою. Польща $є$ не тільки сусідом, але й багаторічним партнером України. Білорусь $є$ сусідом і водночас активно займається досягненням цілей сталого розвитку. Канада, Сполучене Королівство, Німеччина, Франція є країнами з високим рівнем ВВП. Пропонуємо в подальшому використовувати ці країни як орієнтири для аналізу заходів та ініціатив для розвитку промисловості на засадах глобальних цілей сталого розвитку.

Загалом можна визначити такі негативні тенденції, які впливають на розвиток промисловості та $8,9,12$ та 17 Глобальних цілей сталого розвитку (ЦСР):

- за даними перепису населення 2020 року чисельність українців знизилася на 15 млн 3 1991 року;

- високий рівень старіння населення: 23,4\% населення України - старші за 60 років, у той самий час як людей працездатного віку (16-59 років) $60,2 \%[7] ;$

- Війна на Сході України, втрата 15\% промислового виробництва та 115 з 150 вугільних шахт;

- за субіндексом «Інфраструктура» індексу Глобальної конкурентоспроможності Україна посіла 78 місце у 2019 р. 3137 та знизилася на 10 пунктів порівняно з 2014 р. [8].

Завдяки започаткованим реформам та активізації європейських інтеграційних процесів у 2016-2018 рр. економіка України повернулася до фази відновлювального зростання. Покра-

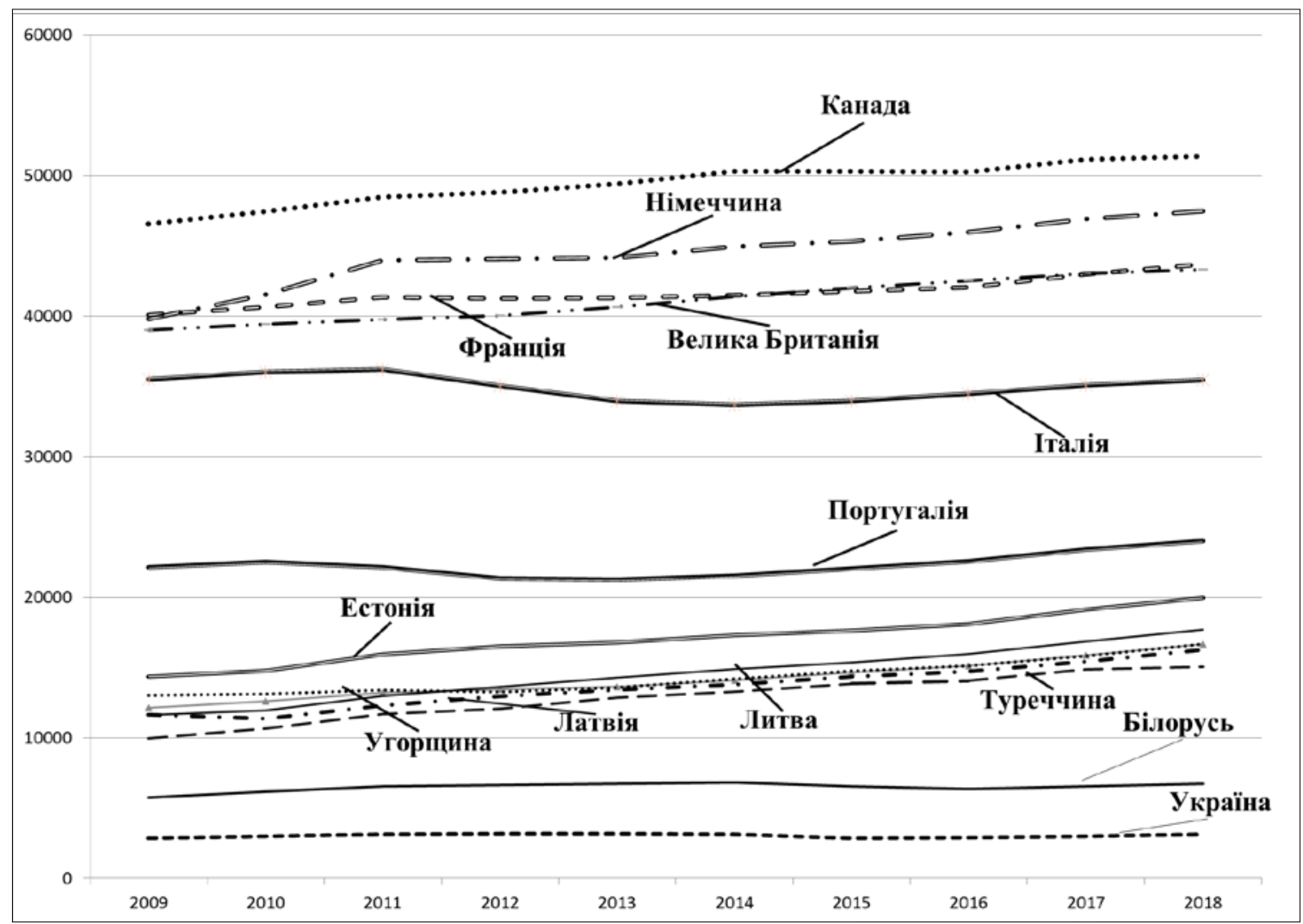

Рисунок 2 - Реальний ВВП на душу населення в досліджуваних країнах з 2009 по 2018 рр. ВВП на душу населення), постійний долар США 2010 року

Джерело: розроблено авторами на основі [6] 
щення ситуації, яке відбулося в економіці та на ринку праці в ці роки, знайшло своє відображення у тенденціях індикаторів ЦСР 8 «Гідна праця та економічне зростання». Так, у цілому по Україні у 2016-2018 роках середньорічний темп зростання ВВП становив 2,7\% , а також:

- зменшився рівень безробіття (3 9,7\% у $2016 \mathrm{p}$ до $8,6 \%$ у 2019 р) [7];

- Україна посіла 47 місце в 2019 році за Глобальним інноваційним індексом 3 індексом 37,47 та динамікою до зростання з 2015 у 2,7\% [9];

- покращення у рейтингу Doing Business (на 10 позицій, до 71-го місця);

- 88-е місце у 2019 році у світі за Індексом людського розвитку з динамікою зростання у 1\% за останні 5 років (хоча водночас це одне 3 найнижчих місць серед країн-сусідів) [10];

- Індекс сприйняття корупції в Україні за період 2013-2018 рр. постійно зростав, а в 2019 році знизився на 2 бали та опинився на рівні 2017 року [11].

Однак зазначені досягнення ще потребують зростання, оскільки в більшості випадків відстають від амбітних значень цільових національних індикаторів, встановлених за ЦСР 8, а отже, потребує розвитку промисловий комплекс України. Зростання економіки України темпами на рівні цільового значення національного індикатора 8.1.1 ЦСР 8 (4\% до 2020 року, 6\% - до 2025 року та $7 \%$ до 2030 року та надалі) залишається одним 3 головних пріоритетів України, реалізація якого дозволить досягти рівня світового розвитку орієнтовно через 52 роки та рівень країн $С \mathrm{C}$ - через 39 років [3].

Відповідно до Експортної стратегії України («дорожня карта» стратегічного розвитку торгівлі) на 2017-2021 роки) пріоритетними для розвитку розширення ринків збуту визначені ринки таких країн, як Китай, Японія, США, Канада, а також ринки СС, САВТ, Азії та Африканського континент. У той же час, у цьому ж документі зазначено, що необхідним $є$ також відновлення своїх позицій на традиційних ринках (СНД), а саме країн Центральної Азії та Закавказзя. В цілому це свідчить про стратегію диверсифікації ринків збуту та підтверджує важливість інноваційного розвитку промисловості.

Зазначимо також, що головною метою Експортної стратегії України до 2021 р. було визначено перехід України до експорту наукомісткої інноваційної продукції для сталого розвитку та успішного виходу на світові ринки. За результатами 2019 року в структурі експорту товарів 3 України основні позиції такі [12]: перше місце - продукція АПК і харчової промисловості вартістю 22146 млн дол США. друге місце - продукція металургійного комплексу - 10257,8 млн дол США, третє місце - продукція машинобудування - 5528,4 млн дол США. При цьому, порівняно з 2018 р. обсяг експорту продукції АПК та харчової промисловості зріс на $19 \%$, а продукції металургійного комплексу знизився на $1 \%$. В структурі експорту послуг перше місце належить транспортним послугам - 9036,4 млн дол США, що становить 59,3\%, комп'ютерні та інформаційні послуги посіли друге місце зі значенням 2433,1 млн дол США, що становить $16 \%$ і на третьому місці послуги 3 переробки матеріальних ресурсів на 2433, 1 дол. США, що становить $10,7 \%$ всього обсягу експорту. При цьому, ще в 2017 p. IT-галузь посідала третє місце за рівнем експорту після експорту послуг переробки матеріальних ресурсів і порівняно з 2018 р. приріст експорту послуг в IT-галузі становив $15 \%$ (зростання на 318,1 млн дол США). Тобто можна констатувати, що хоча мета переходу на експорт наукомісткої інноваційної продукції поки не $є$ досягнутою, проте поступове зростання у даній сфері відбувається.

Коли йдеться про розвиток інфраструктури (ЦСР 9), то, перш за все, мають бути враховані такі складові: транспорт, зв'язок, житлово-комунальне господарство, освіта, медицина та рекреаційна система, соціальне забезпечення, культура, екологія як одні з більш важливих систем для нормального розвитку як регіону, так і країни, в цілому. Аналіз інфраструктури регіонів України на сучасному етапі засвідчив нерівномірний стан та певні диспропорції іiї розвитку. Проблема $\epsilon$ комплексною, але базовий недолік - це невідповідний розподіл та спосіб використання наявних інвестицій. Прискорений доступ до інформаційних ресурсів, розвиток сучасних телекомунікаційних систем, збільшення обсягів вантажопотоків усіма видами транспорту, облаштування транспортних коридорів, розвиток транзитного потенціалу, формування логістичних платформ $\epsilon$ потужним каталізатором модернізації не лише національної економіки, а й регіонів [3]. Це все $\epsilon$ важливою передумовою формування інноваційного промислового комплексу, адже забезпечення інфраструктури надасть змогу спростити низку бізнес-процесів, пов'язаних з виробництво та реалізацією промислової продукції.

Інфраструктура сучасного міста, якість міського середовища визначається діяльністю комплексу галузей міського господарства, що забезпечують населення міста та виробництво. На сьогоднішній день основні напрями ринкової трансформації інфраструктури міст областей нашої країни базуються на відповідних положеннях загальнодержавної програми «Про затвердження Державної стратегії регіонального розвитку на період 2021-2027 роки». Надійна та доступна інфраструктура, що охоплює як дорожньо-транспортні, енергетичні та інформаційно-комунікаційні мережі, так і інноваційну інфраструктуру, $\epsilon$ запорукою ефективної діяльності бізнесу та якісних умов життєдіяльності населення. 
Визначальним фактором прискореного розвитку економіки та, зокрема, промислового комплексу є інформаційно-комунікаційна інфраструктура. Україна входить у Топ-3 країн Центральної та Східної Європи за обсягом IT-ринку та відповідного кадрового потенціалу. Як вже було зазначено, за підсумками 2019 року обсяг експорту IT-технологій, зокрема програмного забезпечення, з України склав 2433,1 млн дол США [13].

Висококваліфіковані ІТ-спеціалісти є однією 3 конкурентних переваг України. Однак, існуюча тенденція до відтоку таких фахівців за кордон свідчить про необхідність негайних заходів щодо збереження кадрового IT-ресурсу в країні та спрямування його потенціалу на цифровізаціюукраїнської промисловості, освоєння підприємствами цифрових бізнес-моделей та платформ взаємодії з клієнтами $з$ метою підвищення результативності роботи та зміцнення конкурентних позицій на ринках.

Сьогодні проводиться робота 3 удосконалення системи наукового та освітнього забезпечення розвитку промисловості, розвиваються умови для використання європейських програм «Розумні спеціалізації», «Європейська кластерна програма», «Горизонт 2020», «Еразмус» тощо.

Щодо досягнення 12 та 17 цілей, то порівняно 3 обраними на початку дослідження країнами, Україна має досить високі результати, очевидно, що обраний політичний вектор, Угода про асоціацію між Україною та ЄС, яка набула чинності 01 вересня 2017 року, відкривають можливості політичної асоціації та економічної інтеграції з $\mathrm{CC}$, що формує можливості для розвитку нових європейських ринків збуту, сприяє лібералізації та розвитку умов торгівлі з країнами СС та позитивно впливає на показники по 12 та 17 цілям. Наприклад, це стимулює підприємства до запровадження принципів відповідального виробництва та споживання, підвищення якості продукції до європейських вимог.

$\mathrm{У}$ той же час, за міжнародний рейтингом за Індексом екологічної ефективності (ЕРI) 2018 р., Україна посіла 109 місце серед 180 країн. У той час як Франція. Нмеччина, Канада посіли, відповідно, 2, 13 та 25 місця, Білорусія - 44 місце [14].

Відповідно до статистистичних даних джерела [15] викиди забруднюючих речовин та діоксиду вуглецю в атмосферне повітря знизилися в 2018 p. порівняно з 2016 р. на 14\%. При цьому дані викиди з боку стаціонарних джерел знизилися більше ніж на 18\%, що свідчить про позитивну тенденцію з боку промислових підприємств.

В Україні діє Національна стратегія управління відходами в Україні до 2030 року, де зазначено, що проблема відходів в Україні вирізняється особливою масштабністю і значимістю як внаслідок домінування у національній економіці ресурсомістких багатовідхідних технологій, так і через відсутність протягом тривалого часу адекватного реагування на іiі виклики. 301 січня 2020 р. було введено в дію Закон України Про Основні засади (стратегію) державної екологічної політики України на період до 2030 року, де зазначено, що серед основних першопричин екологічних проблем України $€$ : фізичне та моральне зношення основних засобів у всіх галузях національної економіки; неефективна система державного управління у сфері охорони навколишнього природного середовища та регулювання використання природних ресурсів, зокрема неузгодженість дій центральних і місцевих органів виконавчої влади та органів місцевого самоврядування, незадовільний стан системи державного моніторингу навколишнього природного середовища; недостатнє фінансування 3 державного та місцевих бюджетів природоохоронних заходів, фінансування таких заходів за залишковим принципом та ін. У даному законі також зазначено, що основні засади екологічної політики тепер будуть підпорядковуватися досягненню Україною Цілей Сталого Розвитку (ЦСР), які були затверджені на Саміті Організації Об'єднаних Націй зі сталого розвитку у 2015 p. Визначені основні показники оцінювання реалізації державної екологічної політики до 2030 р., серед яких частка відновлювальних джерел енергії (включно з гідрогенеруючими потужностями та термальною енергією), водоємність валового внутрішнього продукту, енергомісткість валового внутрішнього продукту, електротранспорт, індекс екологічної ефективності та ін. Можемо відзначити, що цей закон сприяє приведенню української екологічної політики до політики провідних світових країн.

Крім того, 32019 р. застосовується новий порядок справляння і розподілу сум доходів від екологічного податку, зокрема в частині викидів двоокису вуглецю в атмосферне повітря. Розділ VIII Податкового кодексу України змінено Законом України від 23.11.2018 р. № 2628 VIII «Про внесення змін до Податкового кодексу України та деяких законодавчих актів України щодо покращення адміністрування та перегляду ставок окремих податків і зборів» (далі - Закон № 2628) як у частині визначення платників, які справляють екологічний податок за викиди двоокису вуглецю, так і ставок податку. При цьому за зобов'язаннями податку за викиди двоокису вуглецю, що виникають за результатами діяльності у 2019 р., до платників податку в частині викидів двоокису вуглецю належать суб'єкти, у яких сукупний річний обсяг викидів двоокису вуглецю, за даними форми статистичної звітності 2 ТП повітря за 2018 р., копія якої подається до органу ДФС за місцезнаходженням стаціонарного джерела викидів, перевищує 500 тонн. 3 01.01.2019 р. ставку податку за викиди двоокису вуглецю стаціонарними джерелами з 0,41 грн за тонну підвищено до 10 грн за тонну, тобто збільшено у 24,4 рази. Вважаємо, що це $є$ позитивним 
зрушенням і важливо в подальшому співставити викиди промислових підприємств до впровадження податку і після. Це надасть можливість визначити, наскільки ефективним був даний захід.

У той же час, серед недоліків залишається поки не достатнє заохочення промислових підприємств до заміни застарілого обладнання на ефективне та енергозберігаюче, контроль виконання норм на підприємствах, запобігання та визначення корупційної складової.

Стосовно Цілі 17, то як вже було зазначено, Україна, як і інші країни-члени ООН, приєдналася до глобального процесу забезпечення сталого розвитку. Для встановлення стратегічних рамок національного розвитку України на період до 2030 року було започатковано інклюзивний процес адаптації Цілей сталого розвитку. Це дозволяє покращити контрольні заходи, у тому числі, за дотриманням принципів сталого розвитку на промисловості, та підвищити власний рейтинг на світовій арені. Так, відповідно до даних [16] обсяг прямих іноземних інвестицій в 2019 р. склав 3070 млн дол. США, що на 30\% більше ніж в 2018 р., що є найбільшим приростом у порівнянні 32016 р. При цьому сальдо становить 2422 млн дол США. Це є важливим драйвером розвитку промислового виробництва.

Досягнення цілей чи навіть спрямування зусиль на їх досягнення надасть змогу гармонізу- вати низку законодавчих документів $з$ іншими країнами, поліпшити екологію, підняти рівень соціального забезпечення населення, надати поштовх до розвитку економічної системи на новітніх засадах післякарантинних заходів. що запроваджувалися на світовому рівні.

Висновки. 3 використанням положень концепції сталого розвитку було досліджено основні тенденції розвитку промисловості України на засадах Глобальний цілей сталого розвитку, які є визначальними для економічного зростання країни. Проаналізовані основні індикатори досягнення цих цілей, що дозволило проаналізувати прогрес в напрямі розвитку промислового комплексу та необхідного інфраструктурного забезпечення. Зокрема, також виявлено показники інших країн, які були обрані як ключові для порівняння. Це можна врахувати для визначення нової стратегії промисловості України.

Науковою новизною роботи є удосконалення методичних засад використання концептуальних засад сталого розвитку у поєднанні положень Глобальних цілей сталого розвитку з метою реалізації проектів і програм, які стимулюватимуть розвиток промислового потенціалу регіону чи країни.

Подальших розвідок потребує дослідження прогресу та заходів країн $з$ провідною економікою, які увійшли в Топ-20 країн за досягненням цілей сталого розвитку.

\section{Список використаних джерел:}

1. A new Industrial Strategy for a green and digital Europe. Офіційний сайт $C$ C. URL: https://ec.europa.eu/commission/ presscorner/detail/en/ip_20_416 (дата звернення: 20.06.2020).

2. Sustainable Finance: Commission welcomes the adoption. Офіційний сайт CC. URL: https://ec.europa.eu/commission/ presscorner/detail/en/ip_20_1112.

3. Цілі сталого розвитку в Україні. Міністерство економічного розвитку $і$ торгівлі України : веб-сайт. URL: http://un.org.ua/images/SDGs_NationalReportUA_Web_1.pdf (дата звернення: 10.12.2019).

4. Міністерство розвитку економіки, торгівлі та сільського господарства. Офіційний сайт. URL: https://www.me.gov. ua/News/Detail?lang=uk-UA\&id=06566cc3-d3c8-40e7-a728-db6b42d30141\&title=KomentarSchodoFaktoriv-YakiMaliVpliv NaEkonomichnuAktivnistu2019-Rotsi] (дата звернення: 05.04.2020).

5. Державна служба статистики. Офіційний сайт. URL: http://www.ukrstat.gov.ua/ (дата звернення: 05.04.2020).

6. Knoema. Світові дані. URL: https://knoema.com/ (дата звернення: 01.03.2020).

7. Рівень безробіття в Україні: URL:https://index.minfin.com.ua/ua/labour/unemploy/(Last accessed: 20.03.2020).

8. The Global Competitiveness Report. World economic forum URL: http://www3.weforum.org/docs/WEF_TheGlobalCompetitivenessReport2019.pdf (дата звернення: 01.03.2020).

9. The Global Innovation Index. URL: https:/www.globalinnovationindex.org/ (дата звернення: 01.03.2020).

10. Human Development Index Ranking UNITED NATIONS DEVELOPMENT PROGRAMME. URL: http://hdr.undp.org/ en/content/2019-human-development-index-ranking (дата звернення: 01.03.2020).

11. Індекс сприйняття корупції. Transparency International Ukraine. URL: https://ti-ukraine.org/research/indeksspryjnyattya-koruptsiyi-2019/?fbclid=IwAR2N3OD0jFYTWpBn4IVH8npGV2rdo4RaKiJ9IM3OT0wv4qXYVmRwJWqoYNw (дата звернення: 12.03.2020).

12. Інфографіка (експорт). (2020, March 10). Міністерство розвитку економіки, торгівлі та сільського господарства. URL:https://www.me.gov.ua/Documents/List?lang=uk-UA\&id=e3c3c882-4b68-4f23-8e25-388526eb71c3\&tag=TendentsiiEksportu Infografika-eksport- (дата звернення: 12.03.2020).

13. Export Strategy for Creative Industries Sector. (2019, December 26). URL:https://www.me.gov.ua/Documents/ List?lang=uk-UA\&id=994b0513-1759-4b3b-a80a-0e70f015017d\&tag=CektorKreativnikhIndustrii (дата звернення:: 28.03.2020).

14. Environmental Performance Index (EPI). Results Overview. URL: https://epi.yale.edu/epi-results/2020/component/epi

15. Звіт про стратегічну екологічну оцінку URL:http://mpe.kmu.gov.ua/minugol/control/uk/publish/article?art_ $\mathrm{id}=245383233 \&$ cat $\mathrm{id}=244946928$ (дата звернення: 05.02.2020).

16. Прямі іноземні інвестиції (ПІІ) в Україну URL:https://index.minfin.com.ua/ua/economy/fdi/ (дата звернення:: 20.02.2020). 


\section{References}

1. European industrial strategy. (2020, March 13). Available at: https://ec.europa.eu/info/strategy/priorities-2019-2024/ europe-fit-digital-age/european-industrial-strategy_en (accessed 20 June 2020).

2. Sustainable Finance: Commission welcomes the adoption by the European Parliament of the Taxonomy Regulation. (2020, June 19). Available at: https://europeansting.com/2020/06/19/sustainable-finance-commission-welcomes-the-adoption-by-the-european-parliament-of-the-taxonomy-regulation/ (accessed 20 June 2020).

3. Ministry of Economic Development and Trade of Ukraine (2017) Sustainable Development Goals: Ukraine, Available at: http://un.org.ua/images/SDGs_NationalReportUA_Web_1.pdf (Accessed: 10.12.2019).

4. Ministry of Economic Development and Trade of Ukraine (2020). Official web-site. Available at: https://www.me.gov.ua/News/Detail?lang=uk-UA\&id=06566cc3-d3c8-40e7-a728-db6b42d30141\&title=Komentar SchodoFaktoriv-YakiMaliVplivNaEkonomichnuAktivnistu2019-Rotsi] (Accessed: 05.04.2020).

5. Ukrstat (2020), "Economic statistics", available at: http://www.ukrstat.gov.ua/ (Accessed 5 April 2020).

6. Knoema (2020), "World data", available at: https://knoema.com/ (Accessed 1 March 2020).

7. Ministry of Finance of Ukraine (2020), "Unemployment rate in Ukraine", available at: https://index.minfin.com.ua/ ua/labour/unemploy/ (Accessed 20 March 2020).

8. World economic forum (2020), "The Global Competitiveness Report", available at: http://www3.weforum.org/ docs/WEF TheGlobalCompetitivenessReport2019.pdf (Accessed 1 March 2020).

9. Globalinnovationindex.org (2020), "The Global Innovation Index", available at: https://www.globalinnovationindex.org/ (Accessed 1 March 2020).

10. UNITED NATIONS DEVELOPMENT PROGRAMME (2020), "Human Development Index Ranking", available at: http://hdr.undp.org/en/content/2019-human-development-index-ranking (Accessed 1 March 2020).

11. Transparency International Ukraine (2020), "Corruption Perceptions Index", available at: https://ti-ukraine. org/research/indeks-spryjnyattya-koruptsiyi-2019/?fbclid=IwAR2N3OD0jFYTWpBn4IVH8npGV2rdo4RaKiJ9IM3O T0wv4qXYVmRwJWqoYNw (Accessed 12 March 2020).

12. Ministry of Economic Development and Trade of Ukraine (2020), "Infographics (export)", available at: https://www.me.gov.ua/Documents/List?lang=uk-UA\&id=e3c3c882-4b68-4f23-8e25-388526eb71c3\&tag= TendentsiiEksportuInfografika-eksport- (Accessed 12 March 2020).

13. Ministry of Economic Development and Trade of Ukraine (2020), "Export Strategy for Creative Industries Sector", available at: URL:https://www.me.gov.ua/Documents/List?lang=uk-UA\&id=994b0513-1759-4b3b-a80a0e70f015017d\&tag=CektorKreativnikhIndustrii (Accessed 28 March 2020).

14. Environmental Performance Index (2020, "Results Overview", available at: https://epi.yale.edu/epi-results/2020/ component/epi. (Accessed 28 March 2020).

15. Ministry of Energy of Ukraine (2020), "Strategic Environmental Assessment Report, available at: http://mpe.kmu.gov.ua/minugol/control/uk/publish/article?art_id=245383233\&cat_id=244946928. (Accessed 20 February 2020 ).

16. Ministry of Finance of Ukraine (2020), "Foreign direct investment (FDI) in Ukraine", available at: https://index.minfin.com.ua/ua/economy/fdi/ (Accessed 20 February 2020). 
Trofymenko Olena

International University of Finance; National Technical University of Ukraine "Igor Sikorsky Kyiv Polytechnic Institute»

Doroshkevych Dariia International University of Finance; National Technical University of Ukraine "Igor Sikorsky Kyiv Polytechnic Institute»

Dzhadan Irina

International University of Finance;

National Institute for Strategic Studies

\section{USING THE PRINCIPLES OF GLOBAL GOALS OF SUSTAINABLE DEVELOPMENT TO ENSURE THE DEVELOPMENT OF UKRAINIAN INDUSTRY}

The main tendencies of industrial development of Ukraine are investigated in the article. The main Global Sustainable Development Goals have been selected, based on which the development of Ukraine's industry should be ensured, namely: Goal 8 "Decent work and economic growth", Goal 9 "Innovation and infrastructure", Goal 12 "Responsible consumption", Goal 17 "Cooperation to achieve goals". The basic preconditions of industrial development are investigated. The dynamics of indices of gross domestic product and industrial products is compared. The main countries that should be used as benchmarks for the analysis of progress in achieving the goals of sustainable development and industrial development are identified. The dynamics of real GDP per capita in the studied countries and in Ukraine is given. The main negative and positive aspects of industrial development are determined on the basis of global goals of sustainable development. Some indicators of the effectiveness of measures to achieve certain goals of sustainable development in Ukraine are studied. The commodity structure of Ukraine's exports and the main priorities of Ukraine's Export Strategy are analyzed, taking into account the main indicators of industrial output. Namely. the volumes of products of the agro-industrial complex and food industry, metallurgical complex, mechanical engineering, high-tech products are compared. The main components of the infrastructure of the industry are identified. It is noted that the information and communication infrastructure is one of the determining factors of accelerated economic development and defined systems of scientific and educational support for industrial development. The scientific novelty of the study is to improve the methodological framework for the use of conceptual principles of sustainable development in combination with the provisions of the Global Sustainable Development Goals in order to implement projects and programs that will stimulate the development of industrial potential of the region or country.

Key words: industry, sustainable development, global goals of sustainable development.

JEL classification: E17, E123 